24 Cook JD, Skikne BS, Lynch SR, Reusser ME. Estimates of iron sufficiency in the US population. Blood 1986;68:726-31.

Bainton DF, Finch CA. The diagnosis of iron deficiency anemia. Am 7 Med $1964: 37: 62-70$

26 Macdougall IC, Roberts DE, Neubert $P$, Dharmasena AD, Coles GA, Williams JD. Pharmacokinetics of recombinant human erythropoietin in patients on continuous ambulatory peritoneal dialysis. Lancet 1989;i:425-7.

27 Boelaert JR, Schurgers ML, Matthys EG, et al. Comparative pharmacokinetics of recombinant erythropoietin administered by the intravenous, subcutaneous and intraperitoneal routes in continuous ambulatory peritoneal dialysis patients. Perit Dial Int 1989;9:95-8.

28 Frenken LAM, Coppens PJW, Tiggeler RGWL, Koene RAP. Intraperitoneal erythropoietin. Lancet 1988;ii:1495.

29 Macdougall IC, Cavill I, Davies ME, Hutton RD, Coles GA, Williams JD. Subcutaneous recombinant erythropoietin in the treatment of renal anaemia in CAPD patients. Contrib Nephrol 1989;76:219-26.

30 Macdougall IC, Roberts DE, Coles GA, Williams JD. Intraperitoneal erythropoietin. Lancet 1989;i:1389.

1 Bommer J, Ritz E, Weinreich T, Bommer G, Ziegler T. Subcutaneous erythropoietin Lancet 1988;ii:406.

32 Stevens JM, Strong CA, Oliver DO, Winearls CG, Cotes PM. Subcutaneous erythropoietin and peritoneal dialysis. Lancet 1989;i:1388-9.

33 Granolleras C, Branger B, Beau MC, Deschodt G, Alsabadani B, Shaldon S. Experience with daily self-administered subcutaneous erythropoietin. Contrib Nephrol 1989:76:143-8.

34 Mayer G, Thum J, Cada EM, Stummvoll HK, Graf H. Working capacity is increased following recombinant human erythropoietin treatment. Kidney Int 1988;34:525-8

35 Tsutsui M, Suzuki M, Hirasawa Y. Renewed cardiovascular dynamics induced by recombinant erythropoietin administration. Nephrol Dial Transplant 1989;4 (suppl): $146-50$

36 Grutzmacher P, Ehmer B, Messinger D, Scigalla P. Effect of aluminium overload and hyperparathyroidism on bone marrow response to recombinant human erythropoietin therapy. Nephrol Dial Transplant 1989;4:474.

37 Meytes D, Bogin E, Ma C, Dukes PP, Massry SG. Effects of parathyroid hormone on erythropoiesis. $\mathcal{f}$ Clin Invest 1981;67:1263-9.
$38 \mathrm{Hampl} \mathrm{H}$, Riedel E, Wendel G, Stabell U, Kessel M. Influence of parathyroid hormone on exogenous erythropoietin stimulated erythropoiesis in hemodialysis patients. Kidney Int 1988;33:224.

39 Fervenza F, Oliver DO, Forman E, Winearls CG. Autonomous hyperparathyroidism does not cause resistance to recombinant human erythropoietin. Nephrol Dial Transplant 1989;4:472.

40 Valderrabano $F$. Adverse effects of recombinant human erythropoietin in the treatment of anamia in chronic renal failure. Nephrol Dial Transplant 1988;3:503.

41 Canadian Erythropoietin Study Group. The clinical effects and side effects of recombinant human erythropoietin in anemic patients on chronic hemo dialysis. Clin Invest Med 1989;12 (suppl):B66.

42 Levin N. Management of blood pressure changes during recombinant human erythropoietin therapy. Semin Nephrol 1989;9 (suppl 2):16-20.

43 Moia M, Mannucci PM, Vizzotto L, Casati S, Cattaneo M, Ponticelli C. Improvement in the haemostatic defect of uraemia after treatment with recombinant human erythropoietin. Lancet 1987;ii:1227-9.

44 Van Geet C, Hauglustaine D, Verresen L, Vanrusselt M, Vermylen J. Haemostatic effects of recombinant human erythropoietin in chronic heamodialysis patients. Thromb Haemost 1989;61:117-21.

45 Dreyling KW, Steinhauer HB, Geiger H, Horl WH, Schollmeyer P. Platelet function under recombinant human erythropoietin therapy in haemodialysis patients. Nephrol Dial Transplant 1989;4:472.

46 Grutzmacher P, Bergmann M, Schoeppe W, Breddin K. Thrombocyte function and plasmatic coagulation under recombinant human erythropoietin therapy. Nephrol Dial Transplant 1989;4:473.

47 Macdougall IC, Davies ME, Hutton RD, Coles GA, Williams JD. Reduction in protein $C$ and protein $S$ levels after treatment with recombinant erythropoietin. Nephrol Dial Transplant 1989;4:476.

48 Watson AJ. Adverse effects of therapy for the correction of anemia in hemodialysis patients. Semin Nephrol 1989;9 (suppl 1):30-4.

49 Zehnder C. Erythropoietin treatment: influence of haemoglobin concentration on dialyser creatinine clearance in haemodialysed patients. Nephron 1989;51:424-5.

(Accepted 24 fanuary 1990)
Department of Surgery, Raetisches Kantons-und Regionalspital, CH-7000 Chur, Switzerland Alberic Fiennes, MS, Allgöwer trauma scholar Gian Melcher, MD, chief resident

Thomas P Rüedi, MD, chief of surgery

Correspondence to: $\mathrm{Mr}$ Fiennes.

BrMed f 1990;300:659-6

\section{Winter sports injuries in a snowless year: skiing, ice skating, and tobogganing}

\author{
Alberic Fiennes, Gian Melcher, Thomas P Rüedi
}

From 1980 to 1989 an average of 150 million nights were spent in the Swiss Alps ${ }^{1}$ each winter by visitors, most of whom came to ski. In the past few years snowfalls have been late and scanty in many regions, and this year the problem has been even more severe than expected. Climatic variations affect the opportunities for winter sports and therefore the pattern and severity of injuries seen at local and regional hospitals. The same factors have also favoured the preparation of outdoor ice rinks, and in the absence of adequate skiing numerous visitors have turned to the ice as an alternative to a holiday of frustrated inactivity. Other tourists, perhaps believing themselves to be too cautious to skate, have taken to tobogganing.

\section{Skiing}

Case 1-A 19 year old woman with several years' skiing experience fell across her own ski sticks on hard terrain. She completed her descent but was later admitted to a primary hospital complaining of abdominal pain. Her circulation was stable under observation, but laparotomy was performed because of progressive peritoneal irritation. An extensive deep posterior laceration of the right lobe of the liver was débrided, an omental pedicle interposed, and the cavity packed. She subsequently required transfer to our hospital and second look laparotomy at three days, when the pack was removed and a $T$ tube placed in the common bile duct. After four days of intensive support and 14 days of hepatocellular type jaundice she made a full clinical and biochemical recovery, leaving hospital 21 days after the accident.

Case 2-On a crowded and icy piste a 22 year old man collided at speed with a skilift pylon. There was no obvious external injury or loss of consciousness, but progressive hypotension and tachypnoea prompted immediate evacuation by helicopter to our centre. On arrival he had a patent airway, shallow respiration
( $>36 / \mathrm{min}$ ), and central pulses only. Initially semiconscious and agitated, he quickly had a cardiac arrest. In the course of resuscitation immediate laparotomy showed a ruptured liver and diaphragm but little blood. At median sternotomy there was no pericardial tamponade and an empty heart was noted. The right lower lobe vessels and bronchus were found to be avulsed, and resuscitation proved to be impossible.

\section{Ice skating}

Case 3-Following the closure of local ski lifts a 48 year old physically active man was skating on a heavily used village ice rink when his left skate engaged in a deep crevice left by the previous day's skaters. He fell to one side, sustaining a simple short spiral fracture of the tibial isthmus and fibular neck. He was treated at our hospital four hours after injury by open reduction and low contact dynamic compression plating ${ }^{2}$ through an anterolateral approach. Five days later he was discharged partially weightbearing and able to return to his native country by road.

Case 4-An active 68 year old woman hankered after the skating agility of her younger days. On a left turn her poorly sharpened skates slid from under her and she fell on to her left hip. She was helped to her feet and hobbled off the rink in considerable pain, which later drove her to come to our hospital. $x$ Ray films confirmed an impacted subcapital femoral fracture. The fracture position was acceptable, and she was treated by analgesia and carefully supervised mobilisation, being discharged to a rehabilitation unit after 11 days.

Case 5-Prevented by poor local conditions from skiing, a transatlantic visitor of 60 was enjoying a friendly curling match. Enthused by success, he ran up the rink in chase of his winning stone. Turning rapidly to announce victory to his companions, he slipped and fell face forward, sustaining a basal skull fracture, right 
temporomandibular contusion, minor right subfrontal cerebral contusion, and moderately severe concussion, manifest by extensive retrograde amnesia and recurrent vomiting. He required a total of six days bed rest in our hospital.

\section{Tobogganing}

Case 6-Tobogganing on a deserted piste shortly before midnight, a pair of revellers skidded into a safety net with such momentum that both slid under the net and tumbled down the snowless slope beyond, eventually striking some pine trees. One tobogganer, a 34 year old woman, was evacuated by helicopter to our hospital, where she arrived conscious, with a pulse of $110 / \mathrm{min}$, chest wall tenderness, and a rigid abdomen (despite opiates having been given). $x$ Ray films confirmed a fractured rib and pneumoperitoneum. At laparotomy there was a heamatoma of the mesenteric root and subserosal emphysema of the mid-jejunum and ascending colon. A posterior rupture of the duodenum was sutured. After an uneventful recovery she was discharged from hospital 18 days after the accident.

Case 7-A 24 year old general practice assistant used a plastic bag as a toboggan. She lost control on a patch of ice, striking an exposed rock with both feet and tumbling about $100 \mathrm{~m}$ down a bare hillside. At the primary hospital she was noted to have a second degree open fracture dislocation of the right ankle, a second degree open left tibial pilon fracture, an unstable burst fracture of the first lumbar vertebra with impingement into the spinal canal, and mixed motor signs in her legs. After resuscitation she was transferred by helicopter to our hospital, where all three injuries required open reduction and internal fixation (figs 1 and 2). Twenty four hours later her neurological signs had disappeared, and 12 days after the accident she was transferred to a hospital near her home for aftercare.
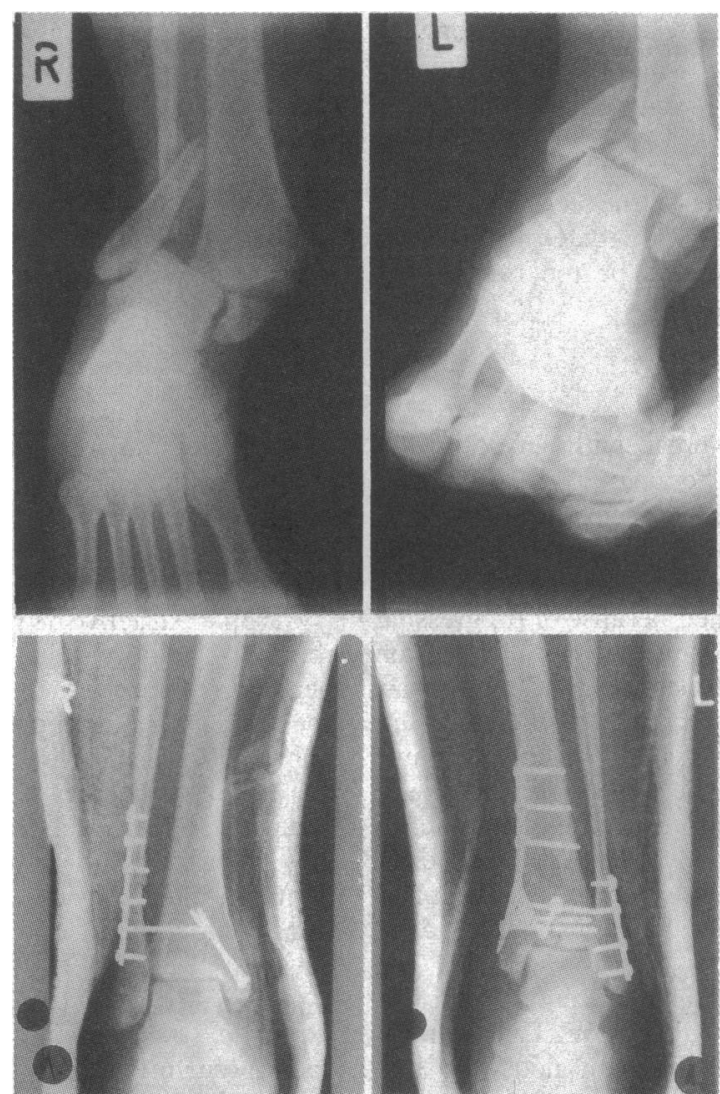

FIG 1-Case 7. Top: Open bimalleolar fracture dislocation of righ ankle and open fracture of left tibial pilon before operation. Bottom: After open reduction and internal fixation

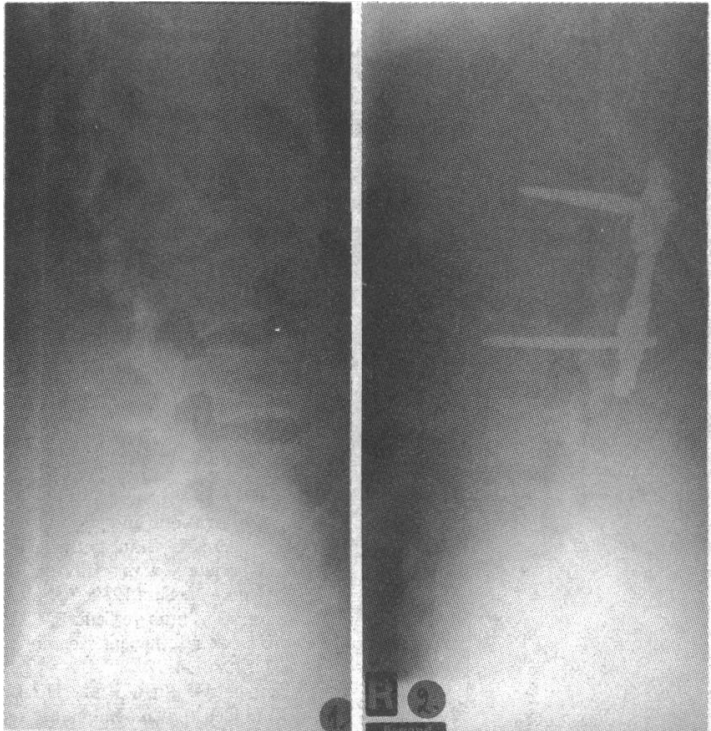

FIG 2-Case 7. Left: Unstable burst fracture of first lumbar vertebra before operation. Right: After reduction and internal fixation by $A O$ internal fixator. Note restoration of vertebral height

Case 8-A 50 year old father was tobogganing pillion behind his young son on a sparsely snow covered but icy slope. He lost control and hurtled toward a retaining wall. Trying to protect his son, he stretched out his right leg as a brake, but his foot struck the wall and father and son were hurled off the toboggan. The son was unhurt, but his father was brought to our hospital with a closed right tibial pilon fracture. After three days of bed rest and leg elevation the fracture was managed by open reduction and internal fixation. $\mathrm{He}$ was discharged non-weightbearing 12 days after injury.

\section{Discussion}

For the decade 1949-59 the Swiss Snow and Avalanche Research Institute in Davos recorded an average depth of snow of $1.56 \mathrm{~m}$ by the 25 January each year (fig 3). This year the depth was $0.72 \mathrm{~m}$ (personal communication). Although many voices have been raised to attribute this change to the greenhouse effect, some famous resorts were without snow for years on end in the mid-nineteenth century.

The popular view of the classic skiing injury is of a fractured ankle or tibia. In fact, changes in the design of ski boots and bindings have for many years shifted the injury pattern in favour of serious ligamentous knee injuries, ${ }^{3+}$ which are rather harder to treat. This hospital normally sees several such injuries every day during the skiing season, but not this year. Any cohort of patients with skiing injuries will contain a proportion of neuroaxial, thoracic, and visceral injuries alongside the usual limb injuries. ${ }^{+5}$ When pistes become few, crowded, and surrounded by uncushioned rocks and trees then life threatening or lethal injury is more likely.

This winter's lack of snow has partly been the result of persistent anticyclonic conditions in December and January. The consequent clear cold nights and sunny days provide enticing conditions on ice rinks, which may be used when skiing is scarce. Our third patient was an adequately competent if unaccustomed skater who was injured by the wear and tear on a busy ice rink. Paradoxically his injury, now rare among skiers, was the classic injury seen in skiers in the past and the one for which dynamic compression plating was perfected. ${ }^{6}$

The general popularity of skating this year may have seduced our fourth patient into an indiscretion she would not otherwise have committed. Falls on ice rinks are inevitably uncushioned and are usually unheralded, 


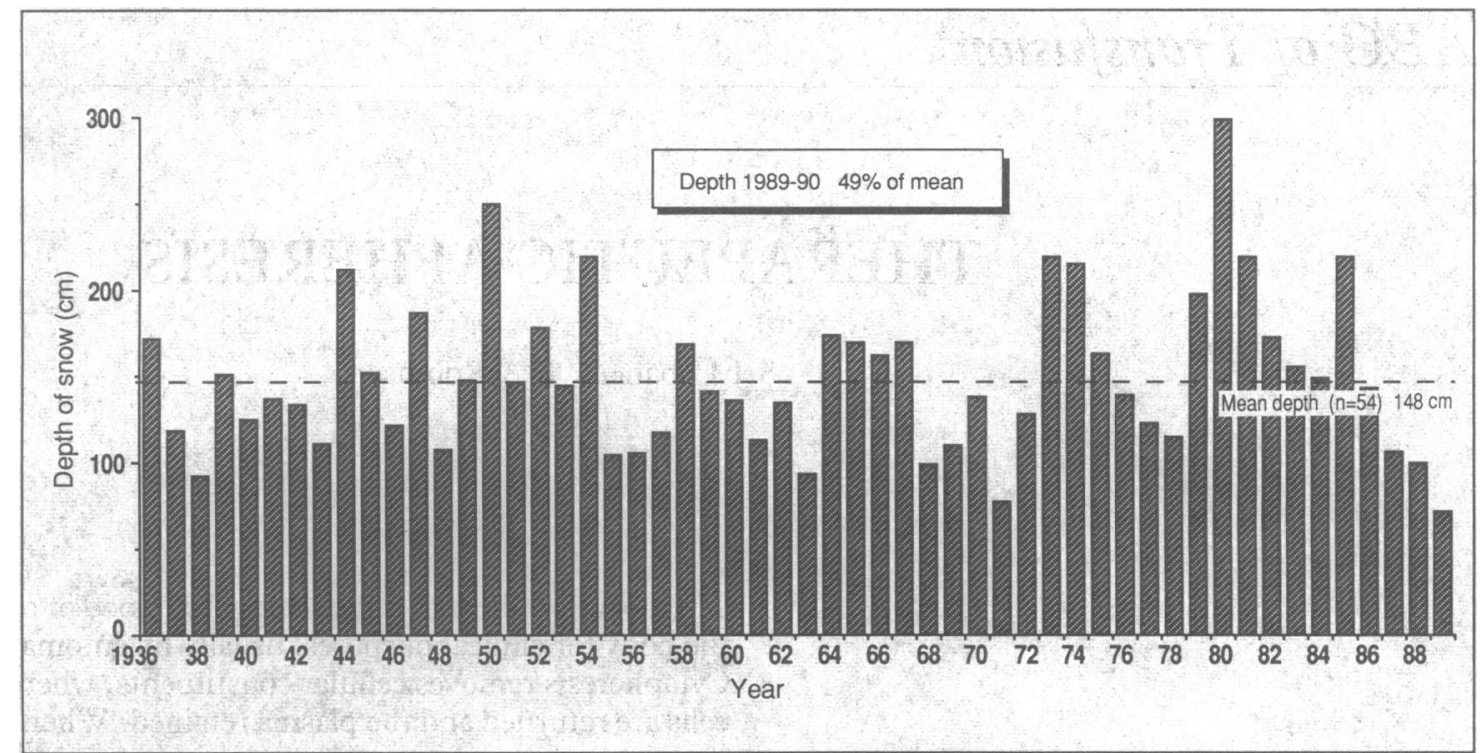

FIG 3-Depth of snow recorded on Weissfluhjoch $(2540 \mathrm{~m})$ on 25 fanuary from 1936-7 to 1989-90. Note that there is no overall trend and that slow fluctuations have occurred in previous years. (Data supplied by Swiss Snow and Avalanche Research Institute, Weissfluhjoch, Davos, Switzerland)

allowing little protective action to be taken. Ice rinks demand careful upkeep in times of heavy use and are hazardous to the inexperienced or inappropriate user - unless they are treated with a degree of care and concentration, which our fifth patient momentarily forgot to exercise.

Like skating, tobogganing requires comparatively little snow. Cold nights and sunny days tend to produce fast, icy, conditions but hard ground. Competitive "skeleton" tobogganing, as practised on the Cresta Run in St Moritz, is notoriously dangerous and has again led to serious injuries this season. In contrast, the public has a benign view of amateur tobogganing that owes much to Christmas cards and the season of good cheer. Cases 6-8 show that this image is not always appropriate. Duodenal injuries are often missed, tibial pilon fractures have long term sequelae ${ }^{8}$ and lumbar burst fractures are associated with paraplegia.

Our case histories show how a lack of snow has shifted the pattern of injuries from winter sports away from simple limb trauma towards serious and sometimes lethal injuries. Amid their splendid scenery most Alpine regions harbour so many historical, aesthetic, and architectural treasures ${ }^{4}$ that visitors need not feel compelled to partake in sporting activity when the conditions make it unduly hazardous. Regional wines and cuisine are also most rewarding but should be mixed with other activities in the correct sequence.

AF is generously supported on a visiting professorship by the AO International Foundation.

1 Swiss Federal Office for Statistics. Tourisme dans quelques centres touristiques et villes. Berne: Swiss Federal Office for Statistics, 1980-9. (Published annually.

2 Perren S, Cordey J, Rahn B, Gautier E, Schneider E. Early temporary porosis of bone induced by internal fixation implants: a reaction to necrosis, not to stress protection? Clin Orthop 1988;232:139-151.

3 Mark G, Scharplatz I), Rüedi T. Entwicklung des Skiunfalls von 1969 his 1979 am Zentralspital cines Bergkantons. Helv Chir Actu 1981;48:35-8.

4 Mark G, Landolt R, Riuedi T Skiunfalle bei Kindern: Entwicklung in 10 Jahren. Pädiatrische Pruxis 1982:26:293-7.

Scharplatz D, Thurlemann K. Fenner A, Enderlin F. Das thorakoabdominale Trauma beim Skisport. Helz Chir Acta 1977;44:81-2.

6 Ruedi T, Webb J, Allgower M. Experience with the dvnamic compression plate DCP) in 418 recent fractures of the tibial shaft. Injurv 1976;7:252-7.

7 Flint LM, McCoy M, Richardson JD, Polk HC. Duodenal injury: analysis of lint LM, McCoy M, Richardson J1), Polk HC. Duedenal injury: analysis of com

8 Ovadia D, Beals R. Fractures of the tibial plafond. 7 Bone foint Surg [Am] $1986 ; 68: 5+3-51$

9 Zeller W. Kunst und Kultur in Graubünden. 2nd ed. Berne: Paul Haupt, 1976.

Accepted 15 Februar 1990

\section{THE MEMOIR CLUB}

Finally, after a great deal of shunting this way and that, the two halves of the train were hooked up and the National Health Service came into being on the appointed day to the tune of a conciliatory message to the medical profession from Aneurin Bevan. Clegg suggested to Bevan that he should make this gesture and Bevan did so in words whose contrast with earlier diatribes was striking. Strangely enough for one so familiar with demagogy, Bevan never seemed to realise that very few doctors had any interest in politics; they felt themselves to be remote from the wrangles and ignorant of the issues, bewildered by "speakers from London" and plebiscite forms. Instead of trying to win their hearts, not in the sense of appealing to them over the heads of their appointed leaders but simply to have the good will of ordinary practising doctors, he was often abusive of the profession in tone and metaphor to such a general extent that, irrespective of his policies, he aroused widespread dislike among people who, if challenged to think about the matter, largely agreed with his plans. This I believe was the greatest single cause of the mistrust of the health service that doctors felt for years after it began. Though he was doubtless prodded beyond the bounds of patience at times by the obstruction, or inertia, or simple disarray of the doctors, he too often lost control of what can well be a politician's greatest asset, a persuasive tongue. His invective tainted an era.
If the disputes over the health service forced the $B M \mathcal{F}$ into an indecisive role from time to time and gave its editor an unpopular image, Clegg himself thoroughly enjoyed the rough and tumble of it all. Having at first thought the service would provide for the medical profession a stable, equable way of life in which medical politics would gradually wither away, we began to learn that the exact reverse was the case: committee work proliferated, larger limousines carried more deputations here and there, legal advisers worked overtime, public relations officers never left the telephone except for another briefing, and relations between different groups of the profession attained a Byzantine complexity. Gone was the pastoral dream of the contented doctor practising medicine in a service whose regularity and harmony had freed him from the attentions of administrators and politicians. Instead BMA committees looked ever more hungrily for space in the $B M \mathcal{F}$, and the growing volume of work bred a new race of virtually whole time medical politicians.

From Reap a Destiny: Divagations of a Taoist by Douglas Swinscow. Published under the BMY's Memoir Club imprint. ISBN 072790255 5. Price: Inland $£ 14.95$; abroad $£ 17.50$; USA $\$ 29.00$. BMA members: Inland £13.95; abroad £16.50; USA $\$ 27.00$. 